\title{
Characteristics of clay minerals in gouges of the Red River fault, Vietnam
}

- Bui Hoang Bac

- Khuong The Hung

- Ngo Xuan Thanh

- Nguyen Tien Dung

Hanoi University of Mining and Geology, Vietnam- buihoangbac@humg.edu.vn

(Manuscript Received on August 12 $2^{\text {th }}$,2014; Manuscript Revised November 11 $1^{\text {th }}, 2014$ )

\begin{abstract}
:
Earthquake is currently one of the biggest concerns in Vietnam, especially, when a number of earthquakes recorded by seismometers in recent years imply the danger of earthquake in the country. In Vietnam, the recorded earthquakes were pinpointed as the consequence of stratigraphic movements along active fault zones. Identifying of the activities of fault is mainly based on tectonics, geomorphology and observation techniques utilizing geophysical methods with data on seismic waves of earthquakes. However, determining the active fault intervals is generally a difficult task which is of the interest of many domestic and worldwide scientists. One of the methods of identifying the active intervals of faults that has been applied in many countries is studying authigenetic clay mineral forming in fault planes and cataclasites due to fault activities. The movement of fault surface will create fault gouges formed at low temperature, the typical of which is illite mineral. In order to date active phases of faults, $K$-Ar dating of illite mineral is now proved to be an effective method. Based on the successful studies on modern fault activities using the method of K-Ar dating of authigeneticillite, and with the goal of having a general view on the activities of Red Rive Fault, Vietnam and more information on earthquakes caused by this fault, the authors have
\end{abstract}

conducted a study on characteristics of the authigenetic clay minerals formed by fault activities, accordingly identifying their formation periods using K-Ar dating method. Based on the recorded ages, we hope to be able to explain the active fault intervals and its relationship with earthquake activity in the surround areas.

In this paper, we are presenting the initial results about characteristics of clay minerals in gouges of the Red River fault zone, Vietnam. Several gouges amples were collected from the Red River fault zone. Then, they were separated into four grain-size fractions $(<0.1,0.1-0.4,0.4$ 1.0 , and $1-2 \mu \mathrm{m})$ using standard gravitational settling and high-speed centrifuging techniques based on a preliminary analysis. The samples after separating were characterized by using FTIR spectroscopy, X-ray diffraction (XRD), Scanning electron microscopy with energy dispersive $X$-ray spectroscopy (SEM-EDX). The results indicated that authigenetic clay minerals forming in fault planes due to fault activities such as illite, illite/smectite is in samples with significant amounts. These are important results in defining modern active time of Red River fault zone using method of K-Ar dating for authigenetic clay minerals.

Keywords: Red River Fault, authigenetic clay mineral, K-Ar dating, illite, illite/smectite. 


\section{INTRODUCTION}

Illite, as a clay mineral, commonly occurs both in middle-low temperature hydrothermal alteration environment, and during burial diagenesis and lowgrade metamorphism. Formation of illite fixes K during burial diagenesisand illite crystallites retain Ar, which allows this system to act a radiometric clock. The ages derived from illite and illite/smectite (I-S) have been used to constrain the geologic timing of hydrothermal fluid migration, regional overthrusting, faulting, and oil and gas migration (Peter, 1999).

Recently, using authigenetic clay minerals, illite, on dating recent active phases of faults are quite common. Lyons and Snellenburg (1971) were the first to determine the absolute age of last activity of the faults by using K-Ar dating techniques on the authigenic illitic fraction in fault gouges (Lyons and Snellenburg, 1971). The reliability of the K-Ar dating of illite mineral in fault gouge has supported by the study of Bonhomme et al., (1983) for the faults in Europe. In recent years, this method has been improved by assisting from the modern techniques and many projects have been gotten successfulness such as those of Choo (2000), Takagi (2005), Zwingmann (2010).

In Vietnam, the recorded earthquake were occurred by movement of land blocks along the active faults, especially big active fault such as the Red River Fault. In recent years, Hanoi and other cities along Red River Fault zone (RRFZ) has been witnessing the dramatically rapid mushrooming of apartment buildings. One burning issue which is interested in by many construction investors, ordinary people and scientists is the possibility of earthquake occurrence caused by this fault. Based on the successful studies on modern fault activities using the method of K-Ar dating of authigenetic illite, and with the goal of having a general view on the activities of Red River Fault and more information on earthquakes caused by this fault, the authors have conducted a study on characteristics of the authigenetic clay minerals formed by fault activities, accordingly identifying their formation periods using $\mathrm{K}-\mathrm{Ar}$ dating method. Based on the recorded ages, we hope to be able to explain the active fault intervals and its relationship with earthquake activity in the surround areas.

In this paper, we are presenting the initial results about characteristics of clay minerals in gouges of the Red River fault zone, Vietnam. Several gouge samples were collected from the Red River fault zone. Then, they were separated into four grain-size fractions $(<0.1,0.1$ $0.4,0.4-1.0$, and $1-2 \mu \mathrm{m})$ using standard gravitational settling and high-speed centrifuging techniques based on a preliminary analysis. The samples after separating were characterized by using FT-IR spectroscopy, X-ray diffraction (XRD), Scanning electron microscopy with energy dispersive X-ray spectroscopy (SEM-EDX).

\section{GEOLOGICAL SETTING OF RED RIVER FAULT}

The Red River Fault Zone is a major tectonic feature separating South China from Indochina blocks. It extends over $1000 \mathrm{~km}$ between eastern Tibet and Tonkin Gulf. The RRFZcomprises four narrow metamorphic massifs, including the Xuelong Shan, the Diancang Shan, the Ailao Shan in China, and the Day Nui Con Voi (DNCV) in Vietnam (Leloup, 1995).

In Vietnam, the Red River Fault Zone runs through series of provinces such as Lao Cai, Yen Bai, Phu Tho, Ha Noi, and Nam Dinh provinces (Figure 1). The core of the RRFZ comprises the metamorphic massif of DNCVwith mylonite bands and amphibolite and marble lenses (Nam et al., 1998). The massif is bounded by the Red River (Song Hong) and Chay River (Song Chay) faults. The DNCV is exposed from the Chinese/Vietnamese boundary at a distance of about $200 \mathrm{~km}$ towards the southeast. Following this direction it is progressively sub-merged and covered by Quaternary sediments of the Red River Delta.

\section{Trang 28}



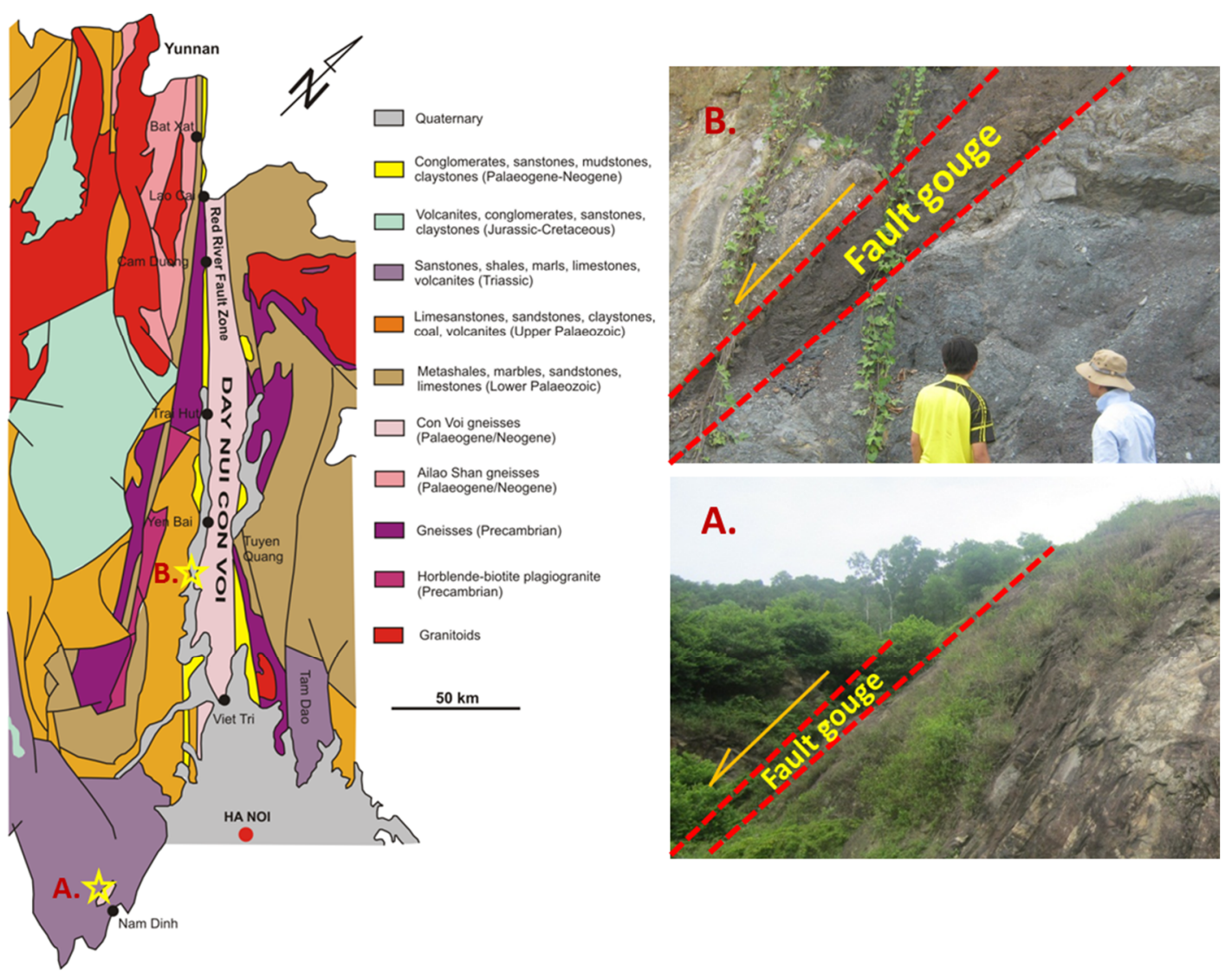

Figure 1. Tectonic sketch-map of the Red River Fault Zone in Vietnam and outcrops

A. The position is at Nam Dinh province. B. The position is at Yen Bai province.

\section{METHODOLOGY}

\subsection{Sample preparation}

In this study, two fault gouge samples were collected from Red River Fault zone, one in Nam Dinh province (sample 1), and other in Yen Bai (sample 2) (Figure 1). The fault gouge samples were washed with deionized water to remove organic substances. For each sample, four grain-size fractions, <0.1, 0.1-0.4, 0.4-1, and 1-2 $\mu \mathrm{m}$, were separated using hydraulic elutriation, centrifuge, and supercentrifuge separators. The suspensions $(<0.1 \mu \mathrm{m}$ fraction) were flocculated by adding $\mathrm{NaCl}$, and the clear supernatant was poured off. All size fractions were dialyzed to remove ions from the suspensions, and were freeze-dried, and then treated with different conditions (room temperature, ethylene glycol, $350^{\circ} \mathrm{C}$ and $550^{\circ} \mathrm{C}$ ) for X-ray diffraction (XRD).For the SEM observation, the fault gouge samples were placed with resin in a vacuum chamber until frothing stops and cut, polished carefully.
The FT-IR spectra for the different grain-size fractions were obtained in transmission mode on pellets containing a pressed mixture of approximately $1.5 \mathrm{mg}$ of the sample and $100 \mathrm{mg}$ of $\mathrm{KBr}$.

\subsection{Analytical methods}

X-ray powder diffraction patterns of the incinerated solid wastes and synthesized minerals were measured using a Mac Science MXP-3 model powder diffractometer with $\mathrm{Cu}-\mathrm{K} \alpha$ radiation at $40 \mathrm{kV}$ and 30 $\mathrm{mA}$. All samples were scanned from 2 to $70^{\circ}$ at a goniometer rate of $2 \theta=2^{\circ} \mathrm{min}^{-1}$.

The SEM-EDS experiments were performed using a low-vacuum (LV)-SEM (JSM-5610LV: JEOL Ltd., Tokyo, Japan) and an EDS system (Oxford Instruments, Abingdon, UK)operating at a 10 Pascal vacuum condition in the backscattered electron (BSE) mode with $20 \mathrm{kV}$ of accelerating voltage without a sample surface coating. 
The IR spectra were recorded in the range between 4000 and $400 \mathrm{~cm}^{-1}$ (PerkinElmer) with 200 scans.

\section{RESULTS}

XRD patterns of the sample 1 and 2 with different size fractions $((1-2 \mu \mathrm{m}),(0.4-1 \mu \mathrm{m}),(0.1-0.4 \mu \mathrm{m})$ and $(<0.1 \mu \mathrm{m}))$ are presented in Figure 1. The results indicated that the sample 1 comprises of kaolinite, mixed-layer illite/smectite, illite and quartz. Clay minerals in the sample 2 are the mixed-layer illite/smectite, kaolinite, chlorite, illite and quartz. When size fraction of sample declines from $(1-2 \mu \mathrm{m})$, $(0.4-1 \mu \mathrm{m}),(0.1-0.4 \mu \mathrm{m})$ to $(<0.1 \mu \mathrm{m})$, the contents of kaolinite, chlorite and quartz also decreases while that of the mixed-layer illite/smectite clay increases.

In the studied samples (Figure 1 and 2), kaolinite is identified by the basal spacing at peaks of $7.17 \AA$ (001) and $5.58 \AA$ (002). These peaks remain unaffected on ethylene glycol and heating $350^{\circ} \mathrm{C}$ conditions, but are destroyed on heating above $550^{\circ} \mathrm{C}$. The basal reflections of illite are recorded at peaks of $10.1 \AA$ (001), $5.03 \AA$ (002) and $3.33 \AA$ (003). On ethylene glycol condition, illite is essentially non-expanding. The (001) peak of illite is collapsed slightly on heating to $550{ }^{\circ} \mathrm{C}$. In general, the basal reflections of illite in both samples are not in high intensity. Chlorite is identified in the sample 2 with peaks of $14.2 \AA$ (001), $4.76 \AA$ (003) and $3.54 \AA$ (004). The (002) peak may be interfered by the (001) peak of kaolinite. The chlorite peaks are not affected on glycolation and heating up to $550^{\circ} \mathrm{C}$. Illite/smectite mixed-layer clay is presented by reflections at $13.9 \AA \AA$ of the sample 1 and $14.2 \AA$ of the sample 2 (Figure 2). For ethylene glycol treated condition, the $13.9 \AA$ peak is shifted to $16.9 \AA$ and the $14.2 \AA$ peak to $9.9 \AA$ A. These peaks are moved to the illite peak of $10.1 \AA$ (001) on heating to $350{ }^{\circ} \mathrm{C}$ and to $550^{\circ} \mathrm{C}$. Clay minerals in the sample 1 and 2 are also presented by results of FT-IR and SEM images (Figure 4 and 5).

The mineralogical composition of $(<0.1 \mu \mathrm{m})$ size fraction in the sample 1 and 2 were estimated based on the relative peak intensities (peak height/ 0.5 by width ratio) of the respective minerals in the XRD charts following Moslehuddin and Egashira (1996). These ratios were obtained by measuring the heights of basal peaks characteristic of the common clay minerals. For kaolinite the $7.17 \AA$ peak, for illite the $10.1 \AA$, for chlorite the $14.2 \AA$ and for illite/smectite the $13.9 \AA$ and $14.2 \AA$ was used. The results show that the sample 1 comprises of about $95 \%$ of illite/smectite, $5 \%$ kaolinite and illite; the sample 2 are about $93 \%$ of illite/smectite, $7 \%$ of kaolinite, illite, chlorite and quartz.

The composition of illite/smectite clay was determined by using the method of Reynolds and Hower (1970), measuring the (002)10/(003)17 peak position from glycolated samples. An increase in the proportion of illite layers in the illite/smectite clays causes this peak to migrate towards $5 \AA$ A Comparing with data from Reynolds, it is seen that the sample 1 contains about 50\% smectite layers and 50\% illite layers. Meanwhile, the sample 2 has about $10 \%$ smectite layers and $90 \%$ illite layers.

\section{CONCLUSION}

In conclusion, clay minerals in gouges of two outcrops along the Red River fault zone were investigated systematically. The samples were separated into four grain-size fractions $(<0.1,0.1-0.4$, 0.4 - 1.0, and $1-2 \mu \mathrm{m})$ using standard gravitational settling and high-speed centrifuging techniques. All the size fractions were characterized by using FT-IR spectroscopy, X-ray diffraction (XRD), Scanning electron microscopy with energy dispersive X-ray spectroscopy (SEM-EDX). The results indicated that clay minerals in the samples are mainly mixed-layer illite/smectite, kaolinite, chlorite, illite and quartz. Significant amounts of mixed-layers illite/smectite means that they maybe were formed by activities of Red River fault. These are initially important results in defining modern active time of Red River fault zone using method of K-Ar dating for authigenetic clay minerals.

Acknowledgements: This research is supported by the Vietnam National Foundation for Science and Technology Development (NAFOSTED) under grant number 105.03-2011.11 to Bui Hoang Bac.

\section{Trang 30}




\section{A. Sample 1}

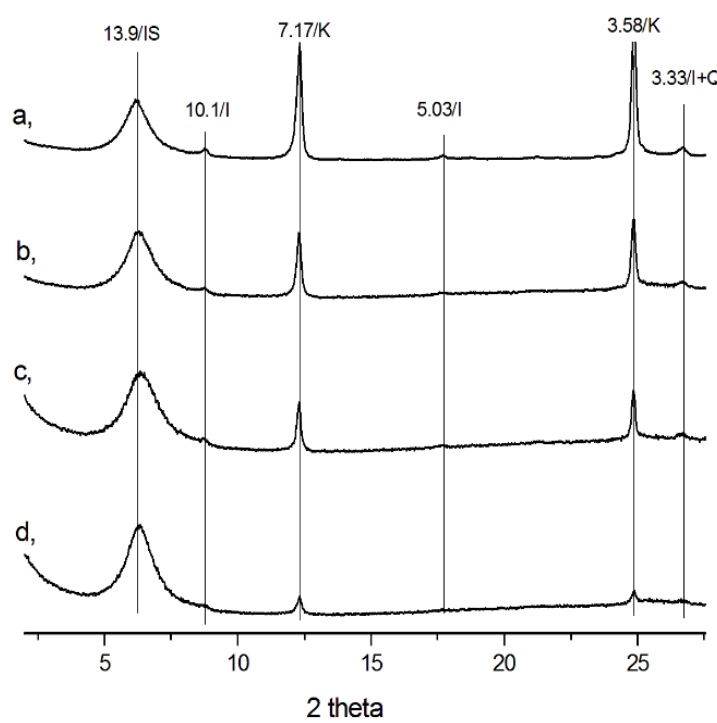

\section{B. Sample 2}

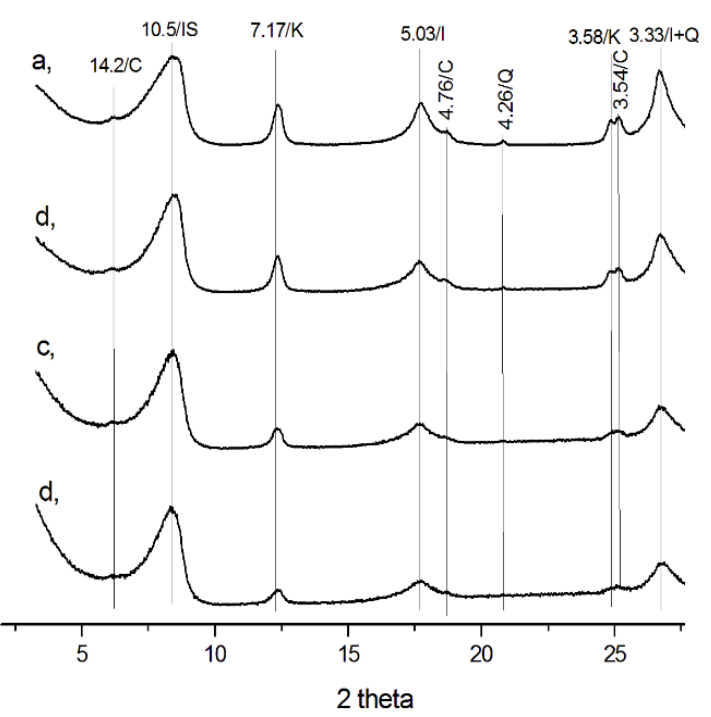

Figure 2. XRD patterns of the sample 1 (A) and sample 2 (B) in different size fractions. Size fraction of $(1-2 \mu \mathrm{m})=\mathrm{a} ;(0,4-1 \mu \mathrm{m})=$ $\mathrm{b} ;(0,1-0,4 \mu \mathrm{m})=\mathrm{c}$ và $(<0,1 \mu \mathrm{m})=\mathrm{d}$.

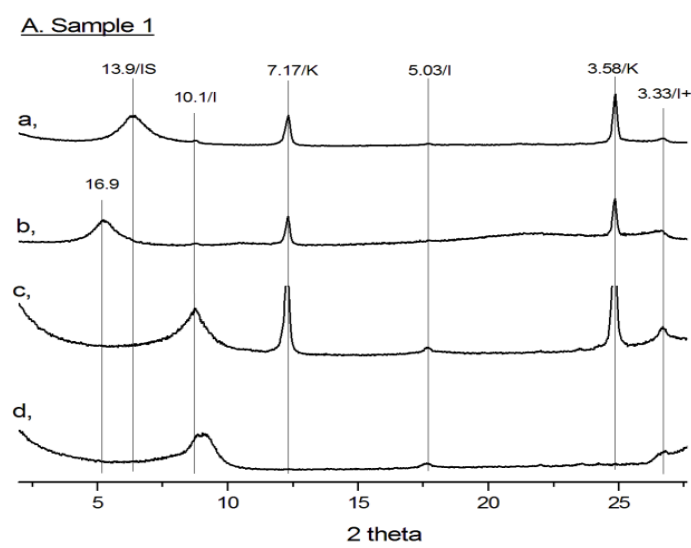

\section{B. Sample 2}

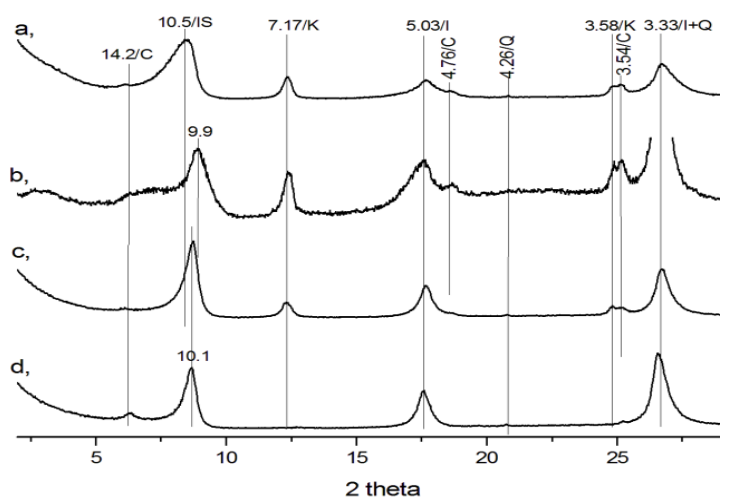

Figure 3. XRD pattern of the sample 1 (A) and sample 2 (B) of the size fraction of $(0,4-1 \mu \mathrm{m})$ in different conditions. At room temperature (a), ethylene glycol (b), at $350{ }^{\circ} \mathrm{C}(\mathrm{c})$ và $550^{\circ} \mathrm{C}(\mathrm{d})$.
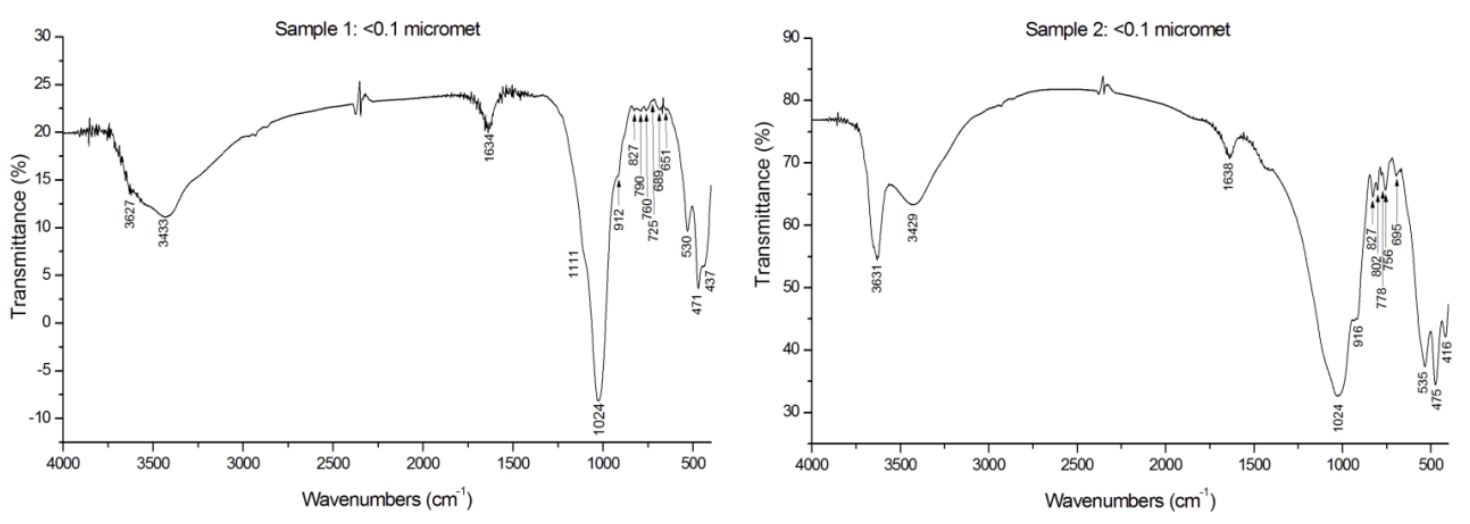

Figure 4. Infrared spectra of the sample 1 and sample 2 of the $(0,4-1 \mu \mathrm{m})$ size fraction. 


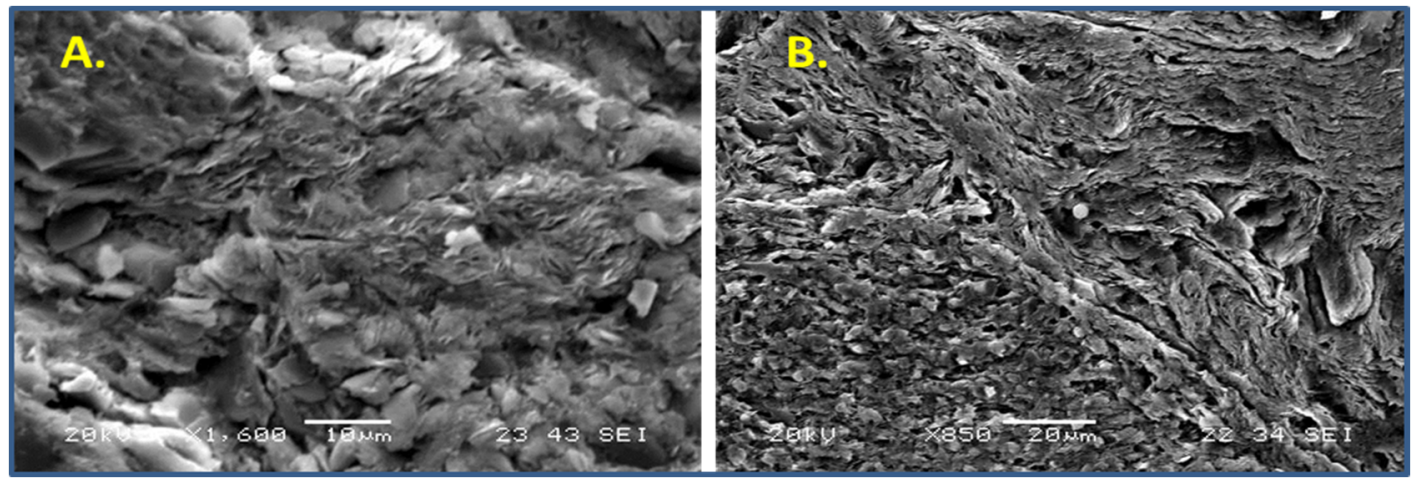

Figure 5. SEM images of the sample 1 (A) and sample 2 (B).

\section{Đặc tính khoáng vật sét sinh thành ở nhiệt độ thấp dọc mặt trượt của đới đứt gãy Sông Hồng, Việt Nam}

- Bùi Hoàng Bắc

- Khương Thế Hùng

- Ngô Xuân Thành

- Nguyễn Tiến Dũng

Trường Đại học Mỏ - Địa chất Hà Nội- buihoangbac@humg.edu.vn

\section{TÓM TÁT:}

Xác định thời gian hoạt động của các đứt gãy là một vấn đề được các nhà trong và ngoài nước quan tâm. Một trong những phương pháp đã và đang được sử dụng nhiều hiện nay là phương pháp nghiên cứu khoáng vật sét sinh thành do quá trình hoạt động của đứt gãy gây nên. Sự dịch chuyển hai cánh của đứt gãy tạo ra mùn đứt gãy (fault gouges) ở điều kiện nhiệt độ thấp, đặc trưng là khoáng vật sét illite, illite/smectite. Phương pháp định tuổi $K-A r$ các khoáng vật mới sinh thành này là phương pháp mang hiệu quản hằm xác định các giai đoạn hoạt động của đứt gãy xảy ra. Mục tiêu của bài báo nhằm đưa ra kết quảng hiên cứu ban đầu đối với các khoáng vật sét nằm dọc các mặt trượt của đới đứt gãy Sông Hồng, Việt Nam. Hai

Từ khóa: Đưt gãy Sông Hồng; Khoáng vật sét sinh thành trong điều kiện nhiệt độ thấp; Phương pháp định tuổi K-Ar; Khoáng vật illite; Illite/smectite. mẫu mùn trong đới đứt gãy được thu thập dọc đưt gãy Sông Hồng. Các mẫu này được lọc tách thành 4 kích cỡ hạt khác nhau (bao gồm cỡ hạt <0.1, 0.1 $\div 0.4,0.4 \div 1.0$, và $1 \div 2 \mu \mathrm{m})$, sử dụng phương pháp trọng lực kết hợp máy ly tâm tốc độ cao. Các cỡ hạt khác nhau được phân tích sử dụng các máy phân tích như FT-IR, XRD, SEM-EDX. Kết quả chỉ ra rằng trong các mẫu mùn đứt gãy có tồn tại một lượng đáng kể các khoáng vật sét mới sinh thành do hoạt động của đứt gãy tạo nên. Đây là kết quả quan trọng ban đầu trong việc xác định thời gian hoạt động của đứt gãy Sông Hồng sử dụng sét mới. phương pháp định tuổi K-Ar cho các khoáng vật

\section{Trang 32}




\section{TÀI LIỆU THAM KHẢO}

[1]. Bonhomme, M. G., Buhmann D., and Besnus Y., (1983), Reliability of K-Ar dating of clays and silicifications associated with vein mineralizations in western Europe. GeologischeRundschau, v. 72, p. 105-117.

[2]. Choo C.O., Chang T.W., (2000), Characteristics of clay minerals in gouges of teDongrae fault, southeastern korea, and implications for fault activity. Clays and clay minerals, V.48, N.2, 204212.

[3]. LeloupP.H., Lacassin R., Tapponnier P., Scharer U., Zhong D., Liu X., Zhang L., Ji S., Phan Trường Thị, 1995. The Ailao Shan - Red River shear zone, Yunnan, China. Tertiary transform boundary of Indochina. Tectonophysics, $251: 3-84$. Elsevier.

[4]. Lyons, J.B. and Snellenburg, J., (1971), Dating faults. Geological Society of America Bulletin, 82, 1749-1752.

[5]. Nam, T.N., Toriumi, M., Itaya, T., (1998), P-T-t paths and post-meta-morphic exhumation of the
Day Nui Con Voi Shear Zone in Vietnam. Tectonophysics 290, 299 \pm 318 .

[6]. Moslehuddin, A.Z.M and Egashira, K., (1996), Mineralogical composition of some important paddy soils of Bangladesh. Bull. Inst. Trop. Agric. Kyushu Univ., 19: 33-54.

[7]. Peter V., Ben A.P., (1999). Clay gouge. J. of Structural Geology, 21, 1039-1048.

[8]. Reynolds, R.C. and Hower, J. (1970), The nature of interlayering in mixed-layer illitemontmorillonites. Clays Clay Min., 18: 25-36.

[9]. Takagi H., Iwamura, A., Awaji, D., Itaya, T. and Okada, T., (2005) Dating of fault gouges from the major active faults in Southwest Japan: Constraints from integrated $\mathrm{K}-\mathrm{Ar}$ and XRD analyses. AAPG Memoir 85, 287-301.

[10].Zwingmann H., Yamada K., Tagami T., (2010) Timing of brittle deformation within the Nojima fault zone, Japan. Chemical geology, 275, 176-185 